\title{
A SHARP OSTROWSKI-GRÜSS TYPE INEQUALITY
}

\begin{abstract}
ZHENG LIU
Abstract. The main purpose of this paper is to use a variant of Grüss inequality to obtain a sharp Ostrowski-Grüss type inequality for absolutely continuous functions whose derivatives are bounded both above and below almost everywhere. Thus we provide improvement and generalization of some previous results.
\end{abstract}

Mathematics subject classification (2010): 26D15, 41A55.

Keywords and phrases: Grüss inequality; Ostrowski-Grüss inequality; absolutely continuous; sharp bound.

\section{REFERENCES}

[1] P. CERONE AND S. S. DRAGOMIR, Three point quadrature rules involving at most a first derivative, RGMIA Research Report Collection, 2(4)(1999), Article 8.

[2] P. Cerone And S. S. Dragomir, Trapezoidal type rules from an inequalities point of view, RGMIA Research Report Collection, 2(6)(1999), Article 13.

[3] P. Cerone And S. S. Dragomir, Midpoint type rules from an inequalities point of view, RGMIA Research Report Collection, 2(7)(1999), Article 1.

[4] X. L. Cheng, Improvement of some Ostrowski-Grüss type inequalities, Computers Math. Appl. 42(2001), 109-114.

[5] X. L. Cheng And J. Sun, A note on the perturbed trapezoid inequality, J. Inequal. Pure Appl. Math. 3(2)(2002), Article 29.

[6] S. S. Dragomir, P. Cerone And J. Rouneliotis, A new generalization of Ostrowski integral inequality for mappings whose derivatives are bounded and applications in numerical integration and for special means, Appl. Math. Lett. 13(2000), 19-25.

[7] S. S. DRAGOMIR AND S. WANG, An inequality of Ostrowski-Grüss type and its applications to the estimations of error bounds for some special means and for some numerical quadrature rules, Computers Math. Appl. 33(11)(1997), 15-20.

[8] I. Fedotov AND S. S. Dragomir, An inequality of Ostrowski's type and its applications for Simpson's rule in numerical integration and for special means, Math. Inequal. Appl. 2(1999), 491-499.

[9] Z. LiU, On sharp perturbed midpoint inequalities, Tamkang J. Math. 36(2) (2005), 131-136.

[10] Z. LiU, A sharp perturbed trapezoid inequality, submitted.

[11] C. E. M. Pearce, J. PeČarić, N. Ujević and S. VArošanec, Generalizations of some inequalities of Ostrowski-Grüss type, Math. Inequal. Appl. 3(2000), 25-34.

[12] M. MATIĆ, J. PeČARIĆ AND N. Ujević, Improvement and further generalization of inequalities of Ostrowski-Grüss type, Computers Math. Appl. 39(2000), 161-175.

[13] D. S. Mitrinović, J. PeČArić And A. M. Fink, Classsical and New Inequalities in Analysis, Kluwer Academic Publishers, Dordrecht, 1993.

[14] N. UJEVIĆ, A generalization of the pre-Grüss inequality and applications to some quadrature formulae, J. Inequal. Pure Appl. Math. 3(1) (2002), Article 13.

[15] N. UJEvIĆ, Inequalities of Ostrowski type and applications in numerical integration, Applied Mathematics E-Notes, 3(2003), 71-79. 